ISSN 1392-3196 / e-ISSN 2335-8947

Zemdirbyste-Agriculture, vol. 103, No. 4 (2016), p. 369-376

DOI 10.13080/z-a.2016.103.047

\title{
Bread-making potential of selected spring wheat species depending on crop year and production technology intensity
}

\author{
Leszek RACHOŃ ${ }^{1}$, Grzegorz SZUMIŁO ${ }^{1}$, Anna SZAFRAŃSKA², Danuta KOTYRBA ${ }^{2}$ \\ ${ }^{1}$ University of Life Sciences in Lublin \\ Akademicka 13, 20-950 Lublin, Poland
}

${ }^{2}$ Prof. Wacław Dąbrowski Institute of Agricultural and Food Biotechnology

Rakowiecka 36, 02-532 Warsaw, Poland

E-mail: anna.szafranska@ibprs.pl

\begin{abstract}
The aim of this study was to assess the effect of different levels of production technology intensity on grain quality of four species of spring wheat: common wheat (Triticum aestivum ssp. aestivum L.), durum wheat (Triticum durum Desf.), spelt wheat (Triticum aestivum ssp. spelta [L.] Thell) and dicoccum wheat (Triticum dicoccum [Schrank] Schübler). Two levels of production technology intensity were applied in the experiment: medium mineral fertilisation $\left(\mathrm{N}-70, \mathrm{P}-30.5\right.$ and $\left.\mathrm{K}-99.6 \mathrm{~kg} \mathrm{ha}^{-1}\right)$, seed priming and weed control; high mineral fertilisation $(\mathrm{N}$ $-140, \mathrm{P}-30.5$ and $\left.\mathrm{K}-99.6 \mathrm{~kg} \mathrm{ha}^{-1}\right)$, seed priming, weed control, two treatments against diseases, insecticide and growth regulator. Tested wheat grains were collected from the crop years 2011-2013. To assess the baking quality of tested wholegrain flour, gluten quantity and quality, falling number and Mixolab parameters were determined. Rheological properties of wholegrain wheat dough were affected mostly by wheat species and crop year. Among the analysed species, spelt wheat was characterised by the highest wet gluten content, amylolytic activity (C4) and starch retrogradation (C5). Dicoccum wheat was characterised by the lowest gluten content and the lowest resistance time of dough (T1) and stability. Dicoccum wheat had also the highest protein weakening (the lowest Cs and $\mathrm{C} 2$ ). Crop year had a significant effect on starch gelatinisation (C3), amylolytic activity (C4), retrogradation (C5) and gelatinisation time (T3-T2). Wheat cultivated under high level of production technology intensity was characterised by higher gluten content and lower final temperature of starch gelatinisation (D3).
\end{abstract}

Key words: baking quality, common wheat, dicoccum wheat, durum wheat, Mixolab, spelt wheat.

\section{Introduction}

Contemporary agriculture requires the application of plant production systems which integrate, among other things, a reduction of the risk involved in the use of mineral fertilisers and plant protection agents with an increase of biodiversity with simultaneous preservation of high quality of yields produced. In relation to the above, apart from common wheat (Triticum aestivum ssp. aestivum L.) which occurs most frequently in production and processing, increasing interest is focused on durum wheat (T. durum Desf.) and such wheat species as einkorn (T. monococcum L.), emmer (T. dicoccum [Schrank] Schübler) and spelt (T. aestivum ssp. spelta [L.] Thell), belonging to the group of plants that were domesticated the earliest. The revival of those ancient species is related primarily to the growing consumer demand for nutritious and healthy food products, with specific nutritional and taste values (De Vita et al., 2006; Konvalina et al., 2010; Suchowilska et al., 2012). Apart from that, compared to common wheat, those husked wheat species usually have lower requirements as concerns cultivation technology and soil and climate conditions, as well as a considerable competitive ability against weeds, which indicates their potential for cultivation in extensive farming conditions, typical of organic farms, or for

low-investment conventional farms (Cyrkler-Degulis, Bulińska-Radomska, 2006; Kohajdová, Karovičová, 2008; Pagnotta et al., 2009; Konvalina et al., 2012).

Mixolab determines the rheological properties of dough, recorded on a graph. Measuring the consistency of dough over time, with a gradual increase in the applied temperature, enables the user to determine the quality of flour and provides, in a single test, information on water absorption, protein strength (dough development time, kneading stability, gluten quality, protein breakdown) and starch characteristics (gelatinisation, retrogradation, enzymatic activity) and on the interactions among these features (Dubat, 2010). The small weight of the wholegrain flour sample needed to perform the Mixolab test (approx. $50 \mathrm{~g}$ ) makes it useful in breeding programs. In recent years, Mixolab has been extensively used for rapid assessment of the wheat Triticum aestivum quality (Koksel et al., 2009; Caffe-Treml et al., 2010; Dhaka et al. 2012). However, there is insufficient data on the possibility of its use in the process of durum, spelt and dicoccum wheat quality assessment (Bodroža-Solarov et al., 2009; Grobelnik Mlakar et al., 2014; Torbica et al., 2016).

The aim of the study was to estimate grain quality of four spring wheat species: common wheat (Triticum 
aestivum ssp. aestivum L.), durum wheat (Triticum durum Desf.), spelt wheat (Triticum aestivum ssp. spelta [L.] Thell) and dicoccum wheat (Triticum dicoccum [Schrank] Schübler) under the conditions of diversified production technology. Spelt wheat and dicoccum wheat have lower nitrogen requirements than common wheat. The research hypothesis assumed that intensification of production technology can cause changes in grain quality and varied responses of the wheat species studied.

\section{Material and methods}

Plant material. The study included spring forms of common wheat (Triticum aestivum ssp. aestivum L.) cultivar 'Parabola', durum wheat (Triticum durum Desf.) line SMH 87 (selected in the Institute of Plant Genetics, Breeding and Biotechnology, University of Life Sciences in Lublin, Poland), spelt wheat (Triticum aestivum ssp. spelta [L.] Thell.) cv. 'Blauer Samtiger' and dicoccum wheat (Triticum dicoccum [Schrank] Schübler) No. 24062 (sowing material acquired from the National Centre of Plant Gene Resources in Poland). Common wheat cv. 'Parabola', a quality wheat cultivar included in the Polish National List of Agricultural Plant Varieties published yearly by the Research Centre for Cultivar Testing, was planted as a reference cultivar for comparison with the husked wheat species. The sowing material was selected as presented above due to the fact that there were no Polish spring spelt and dicoccum wheat cultivars at the time when the research started. Durum wheat SMH 87 was chosen as the only Polish durum wheat cultivar.

Field trials. Wheat grain was sown at the Felin Experimental Farm of the University of Life Sciences in Lublin, Poland, as a two-factor randomised-block field experiment, in four replicates. The experimental field was located on a soil developed from silts of loess origin, classified as the good wheat complex. The soil was rich in phosphorus and potassium $(\mathrm{P}-78.9$ and $\mathrm{K}-$ $180.1 \mathrm{mg} \mathrm{kg}^{-1}$ of soil), while the content of magnesium in the soil was at a low level $\left(39.5 \mathrm{mg} \mathrm{kg}^{-1}\right)$. Two levels of production technology were applied in the experiment: the medium level: mineral fertilisation $(\mathrm{N}-70, \mathrm{P}-30.5$ and $\left.\mathrm{K}-99.6 \mathrm{~kg} \mathrm{ha}^{-1}\right)$, seed priming and weed control; the high level: increased nitrogen fertilisation $(\mathrm{N}-140, \mathrm{P}-$ 30.5 and $\mathrm{K}-99.6 \mathrm{~kg} \mathrm{ha}^{-1}$ ), seed priming, weed control, two treatments against diseases, insecticide and growth regulator. In the medium level of production technology intensity, the spring wheat was fertilised with nitrogen in the amount of $70 \mathrm{~kg} \mathrm{ha}^{-1}$, in three doses: the first dose $\left(30 \mathrm{~kg} \mathrm{ha}^{-1}\right)$ was applied before sowing, the second dose $\left(20 \mathrm{~kg} \mathrm{ha}^{-1}\right)$ - at the stem elongation stage $(\mathrm{BBCH}$ 35-39), and the final dose (20 kg ha-1) - at the heading stage (BBCH 51-53). In the high level of production technology intensity, nitrogen fertilisation was applied in the amount of $140 \mathrm{~kg} \mathrm{ha}^{-1}$ (in three doses): the first dose $\left(60 \mathrm{~kg} \mathrm{ha}^{-1}\right)$ was applied before sowing, the second dose $\left(40 \mathrm{~kg} \mathrm{ha}^{-1}\right)$ - at the stem elongation stage $(\mathrm{BBCH}$ 35-39), and the third dose (40 $\left.\mathrm{kg} \mathrm{ha}^{-1}\right)$ - at the heading stage $(\mathrm{BBCH}$ 51-53). To provide protection against lodging, at the beginning of the stem elongation stage (BBCH 30-32) the liquid anti-lodging agent 675 SL (a.i. chlormequat chloride, $1.5 \mathrm{dm}^{3} \mathrm{ha}^{-1}$ ) was applied. The treatment against fungal diseases consisted of the application of Tango Star 334 SE (a.i. tridemorph, epoxyconazole, $1.0 \mathrm{dm}^{3} \mathrm{ha}^{-1}$ ) at the beginning of the stem elongation stage (BBCH 30-32), and Artea 330 EC (a.i. propiconazole, cyproconazole, $0.5 \mathrm{dm}^{3} \mathrm{ha}^{-1}$ ) at the end of the heading stage (BBCH 58-59). In the period of pests occurrence, the insecticide Sumi-Alpha 050 EC (a.i. esfenvalerate, $0.25 \mathrm{dm}^{3} \mathrm{ha}^{-1}$ ) was applied. In both levels of production technology the grain was primed presowing with a fungicide Baytan Universal 094 FS (Bayer CropScience) (a.i. triadimenol, imazalil, fuberidazole), at a dose of $400 \mathrm{ml}$ of the fungicide with an addition of $200 \mathrm{ml}$ of water per $100 \mathrm{~kg}$ of grain. Monocotyledonous and dicotyledonous weeds were destroyed chemically at the tillering stage, using herbicides Attribut $70 \mathrm{WG}$ (a.i. propoxycarbazone-sodium, $60 \mathrm{~g} \mathrm{ha}^{-1}$ ) and Sekator 125 OD (a.i. iodosulfuron-methyl-sodium, amidosulfuron, $\left.0.10 \mathrm{dm}^{3} \mathrm{ha}^{-1}\right)$, respectively.

Meteorological conditions during the research period. The weather conditions during the period of the study were significantly diversified (Table 1). Mean air temperatures during spring wheat vegetation period in the experimental years were similar, but about $2^{\circ} \mathrm{C}$ higher in comparison with the long term (1951-2010) average, except for March 2013 when the temperature was $3.4^{\circ} \mathrm{C}$ lower than average. On the other hand, rainfall total was more diversified. In 2011, rainfall was lower by $45.6 \mathrm{~mm}$ than average. The weather conditions during the season of 2011 were not favourable for spring wheat growing, compared with the whole period of investigation. March, April and May 2011 were warm but dry. This kind of weather was not beneficial both for germination and for the first stage of plant development. The weather conditions were also not favourable for grain harvesting in due time. The highest rainfall in July, approximately $107 \mathrm{~mm}$ higher than average, resulted in pre-harvest sprouting, which negatively affected wheat quality and yield. The next growing season, 2012, was favourable for spring wheat, with appropriate amount of rainfall and warm temperature. The rainfall was close to average. During the season of 2013 the total rainfall in the months from March to June was much higher, exceeding the normal by $125.8 \mathrm{~mm}$. That year the snow cover persisted until late March. The highest total rainfall, exceeding the normal by 40.9 and $40 \mathrm{~mm}$, was registered in May and June, respectively.

Table 1. Characteristics of the weather conditions

\begin{tabular}{|c|c|c|c|c|c|c|}
\hline \multirow{2}{*}{ Year } & \multicolumn{6}{|c|}{ Month } \\
\hline & March & April & May & June & July & August \\
\hline \multicolumn{7}{|c|}{ Temperature ${ }^{\circ} \mathrm{C}$} \\
\hline 2011 & 2.3 & 10.3 & 14.2 & 18.6 & 18.4 & 18.8 \\
\hline 2012 & 4.3 & 9.5 & 15.0 & 17.3 & 21.5 & 19.2 \\
\hline 2013 & -2.4 & 8.1 & 15.3 & 18.5 & 19.2 & 19.2 \\
\hline Multiannual period $1951-2010$ & 1.0 & 7.4 & 13.0 & 16.3 & 18.0 & 17.2 \\
\hline \multicolumn{7}{|c|}{ Rainfall mm } \\
\hline 2011 & 8.1 & 29.9 & 42.2 & 67.8 & 189.0 & 65.3 \\
\hline 2012 & 28.6 & 34.0 & 56.3 & 62.8 & 52.3 & 37.6 \\
\hline 2013 & 60.8 & 51.1 & 101.6 & 105.9 & 126.1 & 17.8 \\
\hline Multiannual period $1951-2010$ & 28.0 & 39.0 & 60.7 & 65.9 & 82.0 & 70.7 \\
\hline
\end{tabular}


Baking quality analysis. Gluten content, gluten index (PN-A-74042 - equivalent to ISO 21415-2:2015) and falling number (ISO 3093) were determined in duplicate to assess the baking quality of tested wholegrain flour obtained by Perten 3100 Laboratory Mill (Perten, Sweden). The results met the accuracy requirements specified in the appropriate standard. Rheological properties of dough were studied using the Chopin mixolab (Dubat, 2010). The protocol ChopinWheat+ had the following settings: mixing speed $80 \mathrm{rpm}$, total analysis time $45 \mathrm{~min}$, dough weight $75 \mathrm{~g}$, hydration water temperature $30^{\circ} \mathrm{C}$. Wholegrain flour and water were added accordingly to obtain dough with a maximum consistency of $1.10 \mathrm{Nm}( \pm 0.05 \mathrm{Nm})$ during the first test phase. The Mixolab test was performed using the standard protocol: $8 \mathrm{~min}$ at $30^{\circ} \mathrm{C}$, heating at a rate of $4^{\circ} \mathrm{C} \mathrm{min}{ }^{-1}$ for $15 \mathrm{~min}$, holding at $90^{\circ} \mathrm{C}$ for $7 \mathrm{~min}$, cooling to $50^{\circ} \mathrm{C}$ at a rate of $4^{\circ} \mathrm{C} \mathrm{m^{-1 }}$ for $10 \mathrm{~min}$ and holding at $50^{\circ} \mathrm{C}$ for $5 \mathrm{~min}$.

A typical Mixolab curve is divided into five different stages: 1 - initial kneading, 2 - protein weakening, 3 - starch gelatinisation, 4 - cooking stability and 5 - starch retrogradation (Dubat, 2010). The parameters that are obtained from the Mixolab curve are water absorption (WA, \%), dough development time (T1, min), stability ( $\mathrm{min})$, protein weakening (C2 and the difference between points $\mathrm{C} 1$ and $\mathrm{C} 2$, abbreviated $\mathrm{C} 1-\mathrm{C} 2$, $\mathrm{Nm})$, starch gelatinisation $(\mathrm{C} 3, \mathrm{Nm})$, amylolytic activity $(\mathrm{C} 4, \mathrm{Nm})$ and starch retrogradation $(\mathrm{C} 5, \mathrm{Nm})$. Initial and final temperature of starch gelatinisation (D2 and D3, ${ }^{\circ} \mathrm{C}$, respectively), gelatinisation time $(\mathrm{T} 3-\mathrm{T} 2, \mathrm{~min})$ and curve slopes between $\mathrm{C} 1$ and $\mathrm{C} 2$ (slope $\alpha, \mathrm{Nm} \mathrm{min}^{-1}$ ), $\mathrm{C} 2$ and $\mathrm{C} 3$ (slope $\beta, \mathrm{Nm} \mathrm{min}^{-1}$ ), between $\mathrm{C} 3$ and C4 (slope $\gamma, \mathrm{Nm}$ $\mathrm{min}^{-1}$ ) were also recorded. For this study, also the torque in the $8^{\text {th }}$ minute of Mixolab analyses was checked from the curve (abbreviated Cs), as well as the differences between Cs and C2 (abbreviated Cs-C2, Nm). Typical Mixolab curves for tested wheat species are presented in Figure 1

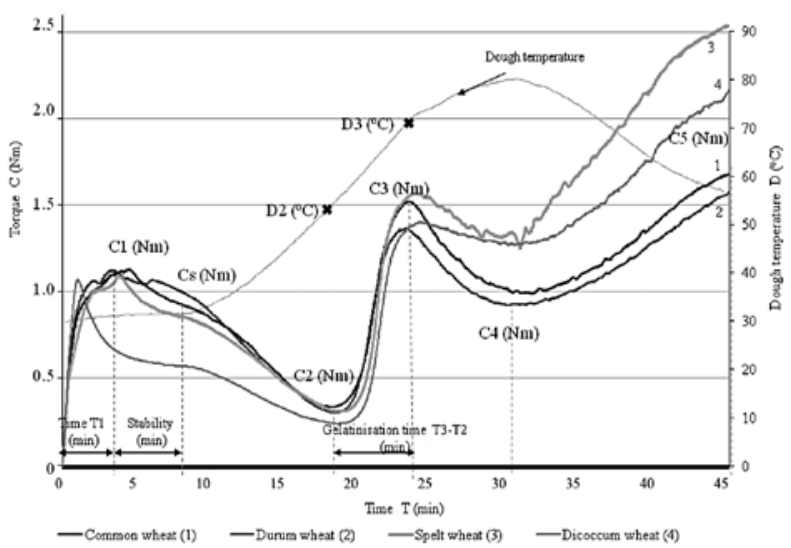

Figure 1. Typical Mixolab curves for the following species of spring wheat: common, durum, spelt and dicoccum (2013 crop, medium level of production technology intensity)

Statistical analysis. The results were statistically evaluated by the three-way analysis of variance ( $A N O V A)$ with subsequent Tukey's HSD test. The three main factors were: wheat species, production technology intensity, and crop year. Correlations between the Mixolab parameters and gluten content and falling number were determined with the statistical significance expression on the level $p<0.05$ and $p<0.01$.
The principal component analysis (PCA) technique was applied because of its ability to reduce the complexity of primary data to a small number of independent principal components representing linear combinations of the possibly correlated original variables. This statistical procedure allows the assessment of the association between groups of variables and explanation of the principal components contributing to the underlying variability of a data set. PCA was applied within the results descriptors in order to characterise and differentiate between the tested species of wheat. Data was analysed using the software StatSoft Statistica, version 12.

\section{Results and discussion}

Gluten content, which is the most important quality parameter of wheat, was in the range of $10.0 \%$ to $52.6 \%$ and depended on wheat species (Table 2). The highest gluten content was found for spelt wheat cv. 'Blauer Samtiger' (44.9\%) and the lowest for dicoccum wheat $(19.3 \%)$, in contrast to the previous study of Konvalina et al. (2010) where dicoccum wheat was described as a high-protein hulled wheat species. Gluten quality of spring dicoccum wheat cultivars in the study of Giacintucci et al. (2014) appeared to be more similar to that of common wheat. Common wheat was characterised by lower level of gluten content than durum wheat and spelt wheat. The same trend was observed in the earlier studies of Bodroža-Solarov et al. (2009), Kohajdová and Karovičová (2009) and Rachoń et al. (2011). The higher level of production technology intensity (including two times higher level of nitrogen fertilisation) caused an increase in average gluten content, similarly to the earlier studies by Woźniak (2006), Rachoń et al. (2013) and Szafrańska et al. (2015). Nowak et al. (2004) noted that different levels of growing technology intensity exert equal influence on the quality of all wheat species. The results of our work showed that common wheat cultivated in the high production technology intensity was characterised by an average $5.8 \%$ higher gluten content than wheat cultivated in the medium production technology intensity. However, in the case of dicoccum wheat there was no effect of the higher production technology intensity on gluten content. The highest gluten content was determined in wheat samples from crop year 2011, and the lowest from the crop year 2013, which was the result of the highest distribution of rainfall during the vegetation period of 2013 . Gluten index of common wheat was in the range of 62 to 89 , which, according to Ionescu and Stoenescu (2010), is suitable for flour for the production of bakery products. Other tested wheat samples, except for two samples of durum wheat, were characterised by gluten index below 50 , which indicates that wheat dough is too weak for bread production. Five of the six dicoccum wheat samples tested were characterised by gluten index lower than or equal to 2 . The poor quality of gluten from dicoccum wheat makes it useless for yeasty products (Konvalina et al., 2010). Concerning the weather conditions, the highest gluten index was observed in 2012, when higher air temperature in combination with lower precipitation promoted the formation of storage proteins. In 2011, the lowest gluten index was caused by wet July because of excessive rainfall before harvest. Spring wheat species tested in this study were characterised by higher gluten quantity and quality than winter wheat species tested by Szafrańska et al. (2015). 
Table 2. Qualitative features of spring wheat species

\begin{tabular}{|c|c|c|c|c|c|c|}
\hline & $\begin{array}{c}\text { Gluten } \\
\text { content } \\
\%\end{array}$ & $\begin{array}{l}\text { Gluten } \\
\text { index }\end{array}$ & $\begin{array}{c}\text { Falling } \\
\text { number } \\
\text { S }\end{array}$ & $\begin{array}{c}\text { Water } \\
\text { absorption (WA) } \\
\% \\
\end{array}$ & $\begin{array}{c}\text { Dough development } \\
\text { time (T1) } \\
\text { min }\end{array}$ & $\begin{array}{l}\text { Dough } \\
\text { stability } \\
\text { min }\end{array}$ \\
\hline \multicolumn{7}{|c|}{ Wheat species } \\
\hline Triticum aestivum & $36.0 \mathrm{~b}^{*}$ & $76 \mathrm{c}^{*}$ & $262 a^{*}$ & $67.2 b^{*}$ & $4.8 c^{*}$ & $7.5 \mathrm{c}^{*}$ \\
\hline T. durum & $39.5 \mathrm{c}^{*}$ & $51 \mathrm{bc}^{*}$ & $262 \mathrm{a}^{*}$ & $65.4 \mathrm{ab}^{*}$ & $3.5 \mathrm{~b} *$ & $8.2 \mathrm{c}^{*}$ \\
\hline T. spelta & $44.9 \mathrm{~d}^{*}$ & $25 \mathrm{ab}^{*}$ & $334 b^{*}$ & $65.2 \mathrm{ab}^{*}$ & $5.0 \mathrm{c}^{*}$ & $5.8 \mathrm{~b}^{*}$ \\
\hline T. dicoccum & $19.3 \mathrm{a}^{*}$ & $8 a^{*}$ & $278 \mathrm{a}^{*}$ & $63.5 \mathrm{a}^{*}$ & $1.3 \mathrm{a}^{*}$ & $1.1 \mathrm{a}^{*}$ \\
\hline \multicolumn{7}{|c|}{ Production technology intensity } \\
\hline Medium & $33.3 \mathrm{a}^{*}$ & $41 \mathrm{a}$ & $273 \mathrm{a}$ & $65.0 \mathrm{a}$ & $3.6 \mathrm{a}$ & $5.7 \mathrm{a}$ \\
\hline High & $36.5 \mathrm{~b} *$ & $39 \mathrm{a}$ & $285 \mathrm{a}$ & $65.6 \mathrm{a}$ & $3.6 \mathrm{a}$ & $5.6 \mathrm{a}$ \\
\hline \multicolumn{7}{|c|}{ Crop year } \\
\hline 2011 & $41.9 c^{*}$ & $31 \mathrm{a}$ & $160 \mathrm{a}^{*}$ & $65.2 \mathrm{a}$ & $4.2 b^{*}$ & $6.4 b^{*}$ \\
\hline 2012 & $33.6 b^{*}$ & $58 \mathrm{~b}$ & $360 b^{*}$ & $65.9 \mathrm{a}$ & $3.6 \mathrm{a}^{*}$ & $6.3 b^{*}$ \\
\hline 2013 & $29.2 \mathrm{a}^{*}$ & $30 \mathrm{a}$ & $334 b^{*}$ & $64.8 \mathrm{a}$ & $3.2 \mathrm{a}^{*}$ & $4.3 \mathrm{a}^{*}$ \\
\hline
\end{tabular}

Note. $\mathrm{a}, \mathrm{b}-$ values marked with the same letters do not differ significantly at $p<0.05$ and $p<0.01(*)$, respectively.

Falling number in tested wheat samples ranged from 62 to $437 \mathrm{~s}$. Values below $200 \mathrm{~s}$ indicate a high level of alpha-amylase activity, whereas values above $300 \mathrm{~s}$ are characteristic of grain with low level of alphaamylase activity. The highest falling number was noted in spelt wheat (Table 2), in contrast to the earlier study of Abdel-Aal et al. (1997) in which common wheat and durum wheat had significantly higher falling number than spelt wheat. Unfavourable weather conditions during vegetation period and harvest had a strong negative effect on the quality of grain from 2011 crop which was characterised by the lowest falling number (160 s), which may indicate sprout damage of grain. The lowest enzymatic activity was detected in 2012, caused by higher than average air temperature and optimum rainfall during grain maturing.

Water absorption, which is an indicator of baking quality, ranged in the tested wheat wholegrain samples from $61.0 \%$ to $69.2 \%$. High protein flour is characterised by high water absorption, which is good for baking performance because it increases the finished product yield and improves shelf life. Common wheat was characterised by significantly higher water absorption than dicoccum wheat (Table 2). There were no significant differences in water absorption between tested spring wheat species according to crop years and growing technology. While the results of our work showed that common wheat cultivated in the high production technology intensity was characterised by an average $1.7 \%$ higher water absorption than wheat cultivated in the medium production technology intensity, the opposite effect (1.9\% lower water absorption) was observed for dicoccum wheat. Substantial rainfall during the vegetation period of 2013, which caused significant lowering of gluten content in tested wheat species, resulted also in the lowest water absorption of wholemeal flour from durum $(65.5 \%)$, spelt $(64.0 \%)$ and dicoccum $(61.8 \%)$ wheat over the entire test period of 2011-2013. However, common wheat was characterised by the highest water absorption in $2013(68.1 \%)$. According to Rachoń et al. (2011), durum wheat was characterised by the highest farinograph water absorption, whereas spelt wheat was characterised by a particularly low level of this parameter. The highest Mixolab water absorption was noted in earlier research for wholegrain common wheat $(69.1 \%)$, whereas lower a value was determined for durum wheat $(67.6 \%)$ and the lowest for spelt wheat (58.0\%) (Mixolab Application Handbook, 2012). The tested spring wheat (common, durum and spelt) species were characterised by higher water absorption (by 4.6, 3.1 and $2.3 \%$, respectively) than winter wheat species tested by Szafrańska et al. (2015).
The strength of a wheat cultivar can be determined from the Mixolab curve on the basis of dough development time (T1), stability during mixing, $\mathrm{C} 2$ and slope $\alpha$ (Caffe-Treml et al., 2010). Time and stability were significantly dependent on wheat species and crop year; however, there was no significant difference with regard to the production technology intensity (Table 2). The shortest dough development time and stability were noted for wheat cultivated in 2013. Wheat grain harvested in 2013 was characterised by low gluten quality as a result of high precipitation in vegetation and harvest periods. Long dough development time and stability indicate that wholegrain wheat is strong. Dicoccum wheat species was characterised by the lowest values of T1 and stability time (1.3 and $1.1 \mathrm{~min}$, respectively) relative to the other tested wheat species, which indicates poor quality of this wheat species. According to Rachon et al. (2011), there was no significant difference between farinograph stability time of common wheat and durum wheat, whereas spelt wheat had the highest value of this parameter. The tested common and durum spring wheat species were characterised by longer dough development time (1.6 and $1.9 \mathrm{~min}$, respectively) and stability (1.3 and $5.2 \mathrm{~min}$, respectively) than winter common and durum wheat tested by Szafrańska et al. (2015). According to the criterion of Dhaka et al. (2012), dicoccum wheat tested in this study is a weak species characterised by low dough stability ( $\leq 4 \mathrm{~min}$ ) (Table 2 ) and C2 values below $0.4 \mathrm{Nm}$ (Table 3), indicating that dough from this species is less tolerant to mixing as compared to the other wheat species. Poor technological quality of spelt wheat cultivars with C2 below $0.3 \mathrm{Nm}$ was noted by Bodroža-Solarov et al. (2009). The slope $\alpha$, related to proteins thermal weakening and indicative of dough strength (Koksel et al., 2009), was significantly dependent on wheat species (Table 3 ). Dicoccum wheat was characterised by the highest value of slope $\alpha$ and the highest values of $\mathrm{C} 1-\mathrm{C} 2$, which reflects the lowest proteolytic activity of that species.

During the Mixolab test the dough and the mixer are kept at $30^{\circ} \mathrm{C}$ for $8 \mathrm{~min}$. As the temperature increases with a gradient of $4^{\circ} \mathrm{C} \mathrm{min}^{-1}$ the consistency of the dough decreases with excessive mixing, which is an indication of protein weakening (Dubat, 2010). The greater the decrease in consistency, the lower the protein quality. For this study, also the torque in the $8^{\text {th }}$ minute of Mixolab analyses was checked from the curve (abbreviated Cs), as well as the differences between $\mathrm{Cs}$ and $\mathrm{C} 2$ (Cs-C2). The highest torque in point $\mathrm{Cs}$, as well as the highest value of $\mathrm{Cs}-\mathrm{C} 2$, were characteristic of durum wheat, whereas the lowest values were observed for dicoccum wheat 
(Table 3), which confirmed the lowest protein quality of this species. Production technology intensity had no effect on protein characteristics of the tested wheat species. The tested wheat cultivated in 2012 crop year was characterised by higher torque in point $\mathrm{C} 2$ and lower differences between $\mathrm{C} 1$ and $\mathrm{C} 2$ than wheat from 2011 and 2013 crop year. Spring wheat species cultivated in 2013 were characterised by the lowest value of Cs and $\mathrm{Cs}-\mathrm{C} 2$, which is related to heavy rain in the vegetation period and confirms the lowest quality of gluten.
The tested wholegrain wheat samples varied in terms of starch properties determined by Mixolab such as gelatinisation $(\mathrm{C} 3$ in the range of 0.86 to $1.68 \mathrm{Nm}$ ), amylolytic activity (C4 in the range of 0.04 to $1.40 \mathrm{Nm}$ ) and retrogradation (C5 in the range of 0.07 to $2.55 \mathrm{Nm}$ ). Spelt wheat, which was characterised by the lowest alpha-amylase activity tested by the falling number method, had the highest stability during heating (C4) and retrogradation (C5) (Table 4). Rain during the harvest in 2011 strongly influenced the amylolytic

Table 3. Rheological properties of whole grain dough from spring wheat in relation to protein characteristics

\begin{tabular}{|c|c|c|c|c|c|}
\hline & $\begin{array}{l}\mathrm{C} 2 \\
\mathrm{Nm}\end{array}$ & $\begin{array}{c}\text { Slope } \alpha \\
\mathrm{Nm}_{\mathrm{min}^{-1}}\end{array}$ & $\begin{array}{c}\mathrm{C} 1-\mathrm{C} 2 \\
\mathrm{Nm}\end{array}$ & $\begin{array}{c}\mathrm{Cs} \\
\mathrm{Nm}\end{array}$ & $\begin{array}{c}\mathrm{Cs}-\mathrm{C} 2 \\
\mathrm{Nm}\end{array}$ \\
\hline \multicolumn{6}{|c|}{ Wheat species } \\
\hline Triticum aestivum & $0.33 \mathrm{~b}^{*}$ & $-0.08 \mathrm{ab}$ & $0.78 \mathrm{a}^{*}$ & $1.01 \mathrm{bc}^{*}$ & $0.68 \mathrm{bc}^{*}$ \\
\hline T. durum & $0.32 \mathrm{~b}^{*}$ & $-0.09 \mathrm{a}$ & $0.79 \mathrm{a}^{*}$ & $1.04 \mathrm{c}^{*}$ & $0.72 \mathrm{c}^{*}$ \\
\hline T. spelta & $0.30 \mathrm{~b}^{*}$ & $-0.07 \mathrm{ab}$ & $0.79 \mathrm{a}^{*}$ & $0.96 \mathrm{~b}^{*}$ & $0.66 \mathrm{~b}^{*}$ \\
\hline T. dicoccum & $0.24 \mathrm{a}^{*}$ & $-0.05 \mathrm{~b}$ & $0.86 \mathrm{~b}^{*}$ & $0.64 \mathrm{a}^{*}$ & $0.41 \mathrm{a}^{*}$ \\
\hline \multicolumn{6}{|c|}{ Production technology intensity } \\
\hline Medium & $0.30 \mathrm{a}$ & $-0.07 \mathrm{a}$ & $0.80 \mathrm{a}$ & $0.91 \mathrm{a}$ & $0.61 \mathrm{a}$ \\
\hline High & $0.30 \mathrm{a}$ & $-0.07 \mathrm{a}$ & $0.81 \mathrm{a}$ & $0.92 \mathrm{a}$ & $0.62 \mathrm{a}$ \\
\hline \multicolumn{6}{|c|}{ Crop year } \\
\hline 2011 & $0.28 \mathrm{a}^{*}$ & $-0.08 \mathrm{a}$ & $0.82 \mathrm{~b}$ & $0.94 \mathrm{~b}^{*}$ & $0.67 \mathrm{~b}^{*}$ \\
\hline 2012 & $0.32 \mathrm{~b}^{*}$ & $-0.06 \mathrm{a}$ & $0.78 \mathrm{a}$ & $0.95 \mathrm{~b}^{*}$ & $0.63 \mathrm{~b}^{*}$ \\
\hline 2013 & $0.29 \mathrm{a}^{*}$ & $-0.07 \mathrm{a}$ & $0.82 \mathrm{~b}$ & $0.84 \mathrm{a}^{*}$ & $0.55 \mathrm{a}^{*}$ \\
\hline
\end{tabular}

Note. $\mathrm{C} 2$ - protein weakening, slope $\alpha$ - curve slope between $\mathrm{C} 1$ and $\mathrm{C} 2, \mathrm{C} 1-\mathrm{C} 2-$ difference between $\mathrm{C} 1$ and $\mathrm{C} 2, \mathrm{Cs}-$ torque in $8^{\text {th }}$ min of the Mixolab test, Cs-C2 - protein quality; a, b - values marked with the same letters do not differ significantly at $p<0.05$ and $p<0.01(*)$, respectively.

Table 4. Rheological properties of whole grain dough from spring wheat in relation to alpha-amylase activity and starch characteristics

\begin{tabular}{|c|c|c|c|c|c|c|c|c|}
\hline & $\begin{array}{l}\mathrm{C} 3 \\
\mathrm{Nm} \\
\end{array}$ & $\begin{array}{l}\mathrm{C} 4 \\
\mathrm{Nm} \\
\end{array}$ & $\begin{array}{l}\mathrm{C} 5 \\
\mathrm{Nm} \\
\end{array}$ & $\begin{array}{c}\text { Slope } \beta \\
\text { Nm } \text { min }^{-1}\end{array}$ & 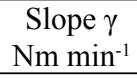 & $\begin{array}{l}\mathrm{D} 2 \\
{ }^{\circ} \mathrm{C} \\
\end{array}$ & $\begin{array}{l}\mathrm{D} 3 \\
{ }^{\circ} \mathrm{C} \\
\end{array}$ & $\begin{array}{c}\text { T3-T2 } \\
\text { min }\end{array}$ \\
\hline \multicolumn{9}{|c|}{ Wheat species } \\
\hline Triticum aestivum & $1.53 \mathrm{~b}^{*}$ & $0.75 \mathrm{a}^{*}$ & $1.24 \mathrm{a}^{*}$ & $0.49 \mathrm{ab}$ & $-0.08 \mathrm{a}^{*}$ & $55.6 \mathrm{a}^{*}$ & $73.0 \mathrm{~b}^{*}$ & $4.8 \mathrm{ab}^{*}$ \\
\hline T. durum & $1.28 \mathrm{a}^{*}$ & $0.84 \mathrm{ab}^{*}$ & $1.30 \mathrm{a}^{*}$ & $0.43 \mathrm{a}$ & $-0.04 b^{*}$ & $55.5 \mathrm{a}^{*}$ & $71.9 \mathrm{a}^{*}$ & $4.4 \mathrm{a}^{*}$ \\
\hline T. spelta & $1.54 \mathrm{~b}^{*}$ & $1.20 \mathrm{c}^{*}$ & $2.09 \mathrm{c}^{*}$ & $0.59 \mathrm{~b}$ & $-0.06 \mathrm{ab}^{*}$ & $56.6 b^{*}$ & $75.7 c^{*}$ & $5.2 \mathrm{c}^{*}$ \\
\hline T. dicoccum & $1.22 \mathrm{a}^{*}$ & $0.99 \mathrm{~b}^{*}$ & $1.79 b^{*}$ & $0.51 \mathrm{ab}$ & $-0.04 b^{*}$ & $57.4 c^{*}$ & $75.7 c^{*}$ & $5.0 \mathrm{bc}^{*}$ \\
\hline \multicolumn{9}{|c|}{ Production technology intensity } \\
\hline Medium & $1.40 \mathrm{a}$ & $0.98 \mathrm{a}$ & $1.64 \mathrm{a}$ & $0.53 \mathrm{a}$ & $-0.05 \mathrm{a}$ & $56.3 \mathrm{a}$ & $74.3 \mathrm{~b}$ & $4.9 \mathrm{a}$ \\
\hline High & $1.38 \mathrm{a}$ & $0.91 \mathrm{a}$ & $1.57 \mathrm{a}$ & $0.48 \mathrm{a}$ & $-0.05 \mathrm{a}$ & $56.2 \mathrm{a}$ & $73.8 \mathrm{a}$ & $4.8 \mathrm{a}$ \\
\hline \multicolumn{9}{|c|}{ Crop year } \\
\hline 2011 & $1.24 \mathrm{a}^{*}$ & $0.52 \mathrm{a}^{*}$ & $0.80 \mathrm{a}^{*}$ & $0.45 \mathrm{a}$ & $-0.06 \mathrm{a}$ & $56.6 b^{*}$ & $72.5 \mathrm{a}^{*}$ & $4.2 \mathrm{a}^{*}$ \\
\hline 2012 & $1.48 \mathrm{~b}^{*}$ & $1.20 \mathrm{~b}^{*}$ & $2.06 b^{*}$ & $0.49 \mathrm{ab}$ & $-0.04 \mathrm{a}$ & $56.8 \mathrm{~b}^{*}$ & $75.6 c^{*}$ & $5.2 b^{*}$ \\
\hline 2013 & $1.45 \mathrm{~b}^{*}$ & $1.11 b^{*}$ & $1.97 b^{*}$ & $0.58 \mathrm{~b}$ & $-0.06 \mathrm{a}$ & $55.3 \mathrm{a}^{*}$ & $74.1 b^{*}$ & $5.2 b^{*}$ \\
\hline
\end{tabular}

Note. C3 - starch gelatinisation, C4 - amylotytic activity, C5 - starch retrogradation, slope $\beta$ - curve slope between C2 and C3, slope $\gamma$ - curve slope between C3 and C4, D2 - initial temperature of gelatinisation, D3 - final temperature of gelatinisation, T3-T2 - gelatinisation time; $\mathrm{a}, \mathrm{b}$ - values marked with the same letters do not differ significantly at $p<0.05$ and $p<0.01(*)$, respectively.

activity measured by Mixolab and caused the lowest values of torque in points $\mathrm{C} 3, \mathrm{C} 4$ and $\mathrm{C} 5$. Winter form of durum wheat tested by Szafrańska et al. (2015) was characterised by much lower gelatinisation, amylolytic activity and retrogradation $(\mathrm{C} 3=0.71, \mathrm{C} 4=0.24$ and $\mathrm{C} 5=0.37$, respectively) than the spring form of durum wheat tested in this study (Table 4). Slope $\beta$ which is an indicator of pasting speed (Koksel et al., 2009) was in the range of 0.24 to $0.70 \mathrm{Nm} \mathrm{min}^{-1}$. Durum wheat had lower slope $\beta$ than spelt wheat, which indicates a slower gelatinisation processes (Caffe-Treml et al., 2010).

Initial temperature of starch gelatinisation (D2) was in the range of $54.6^{\circ} \mathrm{C}$ to $59.3^{\circ} \mathrm{C}$ and final temperature of starch gelatinisation (D3) in the range of 67.6 to $76.4{ }^{\circ} \mathrm{C}$. Significantly higher temperatures D2 and D3 were noted for wholegrain flour dough from spelt and dicoccum wheat than for common and durum wheat (Table 4). Tested wheat species cultivated in the high production technology intensity had significant lower temperature D3. Initial and final temperature of gelatinisation was strongly influenced by the weather conditions during the vegetation period and harvest of the crop year. Final temperature of gelatinisation (D3) of common and durum wheat cultivated in the high production technology intensity was lower by $1.4^{\circ} \mathrm{C}$ and $0.8^{\circ} \mathrm{C}$, respectively, than that of wheat cultivated in the medium production technology intensity. A similar observation was also reported by Szafrańska et al. (2015). The highest final temperature of gelatinisation (D3) was noted for wheat harvested in 2012 and the lowest for 2011 crop year (Table 4). The highest temperature D3 of wheat harvested in 2012 may be the result of much lower rainfall in that year than the average of the multiannual period 1951-2010 (Table 1). Gelatinisation time (T3-T2) of tested spring wheat was in the range of 3.3 to $5.8 \mathrm{~min}$ and varied between wheat species and crop years. The longest gelatinisation time was noted for wholegrain flour dough from spelt wheat and for the crop years 2012 
and 2013. All the tested spring wheat species cultivated in 2011 in the medium production technology intensity were characterised by longer gelatinisation time than wheat cultivated in the high production technology intensity. Common and durum wheat cultivated in 2012 and 2013 exhibited the same trend, whereas for spelt and dicoccum wheat the opposite relationship was noted.

Gluten content was found to be better correlated with torque Cs $(r=0.718)$ and the difference Cs-C2 $(r=0.784)$ than with other Mixolab parameters connected with gluten proteins - dough development time (T1) $(r=0.680)$ and dough stability $(r=0.629)$ (Table 5). There was no significant correlation between gluten content and $\mathrm{C} 2$. The results indicated that the gluten index was significantly correlated with Mixolab stability $(r=0.682)$, torque $\mathrm{C} 2(r=0.750)$, torque Cs $(r=0.660)$ and the difference $\mathrm{C} 1-\mathrm{C} 2(r=-0.622)$.

The positive correlation between slope $\beta$ and falling number $(r=0.594)$ gives indications about the hydrolytic activity of alpha-amylase during the heating period (Table 6). The final temperature of gelatinisation (D3) was highly correlated with falling number $(r=0.734)$, amylolytic activity $(\mathrm{C} 4)(r=0.792)$, retrogradation $(\mathrm{C} 5)$ $(r=0.606)$ and pasting speed (slope $\beta)(r=0.555)$. Tested wheat dough with higher gelatinisation time was characterised by higher gelatinisation (C3), amylolytic activity (C4) and retrogradation (C5).

Table 5. Coefficient of correlation between gluten content and selected Mixolab parameters significant at $p<0.05^{*}$ and $p<0.01 * *$

\begin{tabular}{|c|c|c|c|c|c|c|c|c|c|c|}
\hline & $\begin{array}{l}\text { Gluten } \\
\text { content }\end{array}$ & $\begin{array}{l}\text { Gluten } \\
\text { index }\end{array}$ & $\begin{array}{c}\text { Water } \\
\text { absorption } \\
\text { (WA) }\end{array}$ & $\begin{array}{c}\text { Dough } \\
\text { development } \\
\text { time }(\mathrm{T} 1)\end{array}$ & $\begin{array}{l}\text { Dough } \\
\text { stability }\end{array}$ & $\mathrm{C} 2$ & Slope $\alpha$ & $\mathrm{C} 1-\mathrm{C} 2$ & Cs & Cs-C2 \\
\hline Gluten content & 1 & & & & & & & & & \\
\hline Gluten index & 0.284 & 1 & & & & & & & & \\
\hline Water absorption (WA) & 0.332 & $0.581 * *$ & 1 & & & & & & & \\
\hline $\begin{array}{l}\text { Dough development } \\
\text { time (T1) }\end{array}$ & $0.680^{* *}$ & $0.437^{*}$ & $0.500^{*}$ & 1 & & & & & & \\
\hline Dough stability & $0.629 * *$ & $0.682 * *$ & $0.431^{*}$ & $0.748 * *$ & 1 & & & & & \\
\hline $\mathrm{C} 2$ & 0.314 & $0.750 * *$ & 0.329 & $0.831 * *$ & $0.807 * *$ & 1 & & & & \\
\hline Slope $\alpha$ & $-0.491 *$ & -0.288 & -0.348 & $-0.578 * *$ & $-0.605 * *$ & $0.431 *$ & 1 & & & \\
\hline $\mathrm{C} 1-\mathrm{C} 2$ & -0.285 & $-0.622 * *$ & -0.364 & $-0.641 * *$ & $0.742 * *$ & $-0.872 * *$ & 0.266 & 1 & & \\
\hline $\mathrm{Cs}$ & $0.718^{* *}$ & $0.660 * *$ & $0.535 * *$ & $0.818^{* *}$ & $0.971 * *$ & $0.782 * *$ & $-0.632 * *$ & $-0.723 * *$ & 1 & \\
\hline $\mathrm{Cs}-\mathrm{C} 2$ & $0.784 * *$ & $0.563 * *$ & $0.562 * *$ & $0.812 * *$ & $0.928 * *$ & $0.624 * *$ & $-0.661 * *$ & $-0.598 * *$ & $0.975 * *$ & 1 \\
\hline
\end{tabular}

$\mathrm{C} 2$ - protein weakening, slope $\alpha$ - curve slope between $\mathrm{C} 1$ and $\mathrm{C} 2, \mathrm{C} 1-\mathrm{C} 2-$ difference between $\mathrm{C} 1$ and $\mathrm{C} 2, \mathrm{Cs}-$ torque in $8^{\text {th }}$ minute of the mixolab test, Cs-C2 - protein quality

Table 6. Coefficient of correlation between falling number and selected Mixolab parameters significant at $p<0.05^{*}$ and $p<0.01^{* *}$

\begin{tabular}{cccccccccc}
\hline & Falling number & $\mathrm{C} 3$ & $\mathrm{C} 4$ & $\mathrm{C} 5$ & Slope $\beta$ & Slope $\gamma$ & D2 & D3 & T3-T2 \\
\hline Falling number & 1 & & & & & & & & \\
C3 & $0.730^{* *}$ & 1 & & & & & & \\
C4 & $0.942^{* *}$ & $0.613^{* *}$ & 1 & & & & & \\
C5 & $0.943^{* *}$ & $0.606^{* *}$ & $0.965^{* *}$ & 1 & & & & \\
Slope $\beta$ & $0.594^{* *}$ & $0.681^{* *}$ & $0.582^{* *}$ & $0.668^{* *}$ & 1 & & & \\
Slope $\gamma$ & 0.007 & $-0.415^{*}$ & 0.086 & 0.058 & -0.269 & 1 & & & \\
D2 & 0.031 & -0.158 & 0.083 & 0.143 & 0.012 & 0.018 & 1 & & \\
D3 & $0.734^{* *}$ & $0.470^{*}$ & $0.792^{* *}$ & $0.606^{* *}$ & $0.555^{* *}$ & -0.111 & $0.565^{* *}$ & 1 \\
T3-T2 & $0.865^{* *}$ & $0.606^{* *}$ & $0.896^{* *}$ & $0.888^{* *}$ & $0.578^{* *}$ & -0.015 & 0.093 & $0.606^{* *}$ & 1 \\
\hline
\end{tabular}

C3 - starch gelatinisation, C4 - amylolytic activity, C5 - starch retrogradation, slope $\beta$ - curve slope between C2 and C3, slope $\gamma$ - curve slope between C3 and C4, D2 - initial temperature of gelatinisation, D3 - final temperature of gelatinisation; T3-T2 gelatinisation time

The relationships among the commonly used quality parameters and the rheological properties tested by Mixolab were evaluated by PCA to determine the source of the underlying variability. PCA of quality attributes of gluten protein characteristics, including ten quality parameters (Fig. 2A), showed that $77.69 \%$ of the variations could be explained by the first two principal components (PCs): $\mathrm{PC} 1=63.42 \%$ and $\mathrm{PC} 2=14.27 \%$. The first principal component, representing $63.42 \%$ of the variability, was positively related to the gluten index, Mixolab torque in point $\mathrm{C} 2$, dough development time (T1) and stability, and negatively related to gluten content, Mixolab torque in point $\mathrm{Cs}, \mathrm{C} 1-\mathrm{C} 2, \mathrm{Cs}-\mathrm{C} 2$ and slope $\alpha$. The second principal component, representing $14.27 \%$ of the variability, was positively related to $\mathrm{C} 1-$ $\mathrm{C} 2$ and negatively related to gluten content, gluten index, $\mathrm{C} 2$ and slope $\alpha$. PCA of alpha-amylase activity and starch characteristics of wheat species, including eight quality parameters, showed that $88.8 \%$ of the variations could be explained by the first three principal components: $\mathrm{PC} 1=51.84 \%, \mathrm{PC} 2=20.11 \%$ and $\mathrm{PC} 3=16.80 \%$. The first principal component was positively related to the falling number, Mixolab torque in point $\mathrm{C} 3$ and slope $\beta$, and negatively related to Mixolab torque in point $\mathrm{C} 4$ and C5 (Fig. 2B). The second principal component was positively related to torque in point $\mathrm{C} 3$ and temperature D3, and negatively related to slope $\gamma$ and temperature D2. The third principal component was positively related to slope $\gamma$ and negatively to temperature D2.

Dicoccum wheat, which was negatively related to the first principal component (Fig. 3A), was characterised by lower gluten content, torque in point $\mathrm{Cs}$, $\mathrm{Cs}-\mathrm{C} 2$ and slope $\alpha$ than other wheat species. 
A

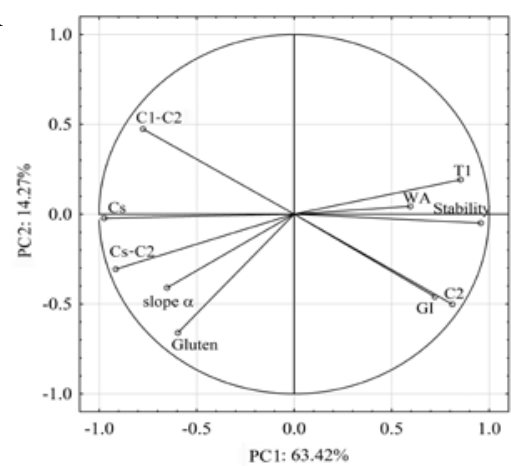

B

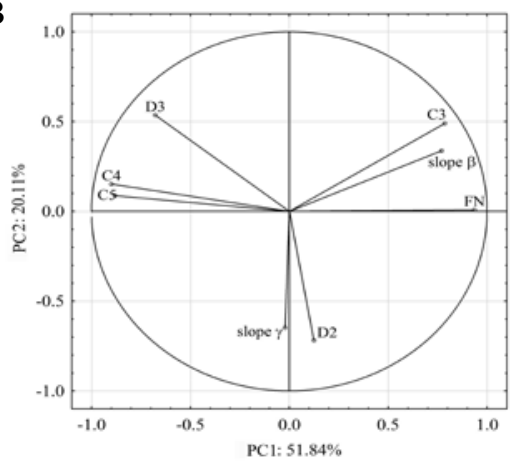

Figure 2. Loading plot of the first and second principal components after principal component analysis (PCA) based on gluten content, gluten index (GI) and Mixolab values (A), and falling number (FN) and selected data of Mixolab values (B) of spring wheat species
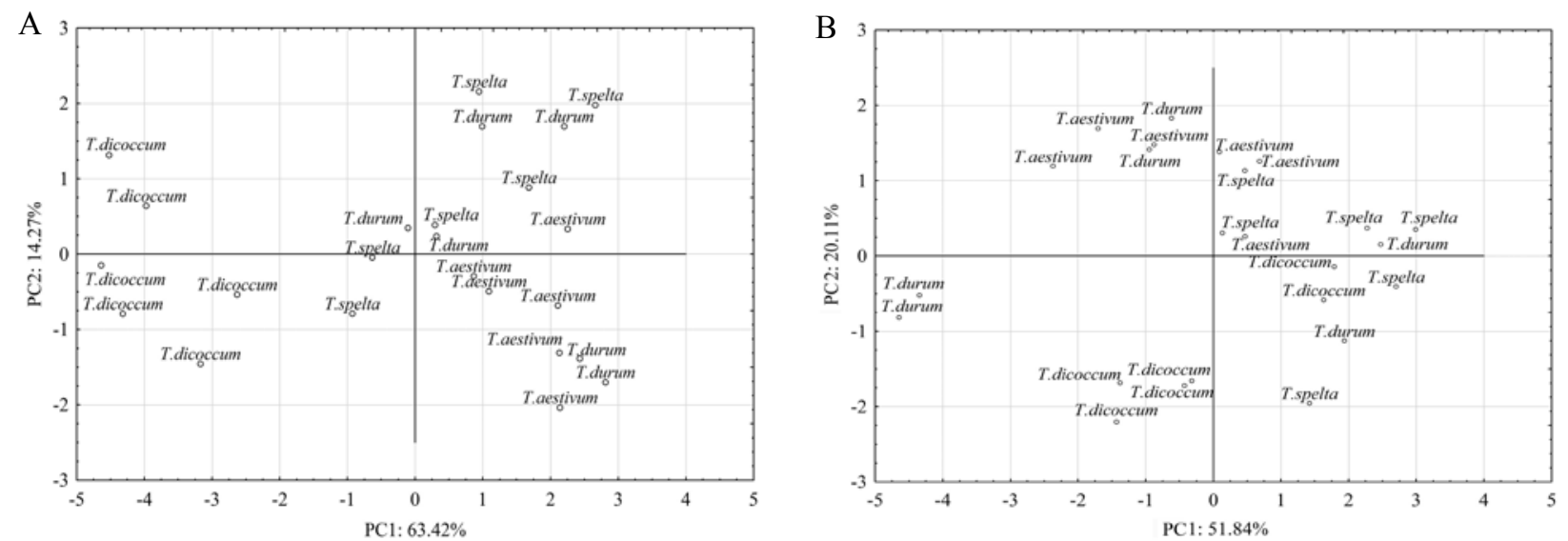

Figure 3. Principal component analysis (PCA) of tested spring wheat species in terms of gluten protein (A) and alphaamylase activity and starch (B) characteristics

\section{Conclusions}

1. The tested spring wheat species differed in protein and starch properties. Spelt wheat was characterised by significantly the highest gluten content and the lowest alpha-amylase activity among all tested wheat species.

2. The rheological properties of wholegrain wheat dough tested by Mixolab were affected mostly by wheat species and crop year. Common wheat was characterised by the highest water absorption (WA), the greatest resistance time of dough (the sum of time (T1) and stability), the lowest amylolytic activity (C4) and retrogradation (C5). Crop year had a significant effect on wet gluten content, resistance time of dough and starch characteristics such as starch gelatinisation (C3), amylolytic activity (C4) and retrogradation (C5).

3 . The intensification of production technology did not cause any significant changes in grain quality parameters, except protein content and starch gelatinisation temperature. Spring wheat species cultivated at the high level of production technology intensity were characterised by significantly higher gluten content and lower final temperature of gelatinisation (D3) than wheat cultivated at the medium production technology intensity.

4. The principal component analysis showed that there were differences between the wheat species. Dicoccum wheat, which was negatively related to the first principal component, i.e. protein quality, was characterised by lower gluten content, highest protein weakening (torque in point $\mathrm{Cs}$ ), lower protein quality (differences between points $\mathrm{Cs}$ and $\mathrm{C} 2$ ) and slope $\alpha$ than the other wheat species.

\section{Acknowledgements}

The research was conducted as part of project No. N N 310306839 and supported by the Polish Ministry of Science and Higher Education.

Received 10062016

Accepted 12102016

\section{References}

Abdel-Aal E.-S. M., Hucl P., Sosulski F. W., Bhirud P. R. 1997. Kernel, milling and baking properties of springtype spelt and einkorn wheats. Iournal of Cereal Science, 26: 363-370 http://dx.doi.org/10.1006/jers.1997.0139

Bodroža-Solarov M., Mastilovic J., Hilipčev B., Šimurina O. 2009. Triticum aestivum spp. spelta - the potential for the organic wheat production. Progress of Theoretical and Experimental Physics, 13 (2): 128-131

Caffe-Treml M., Glover K. D., Krishnan P. G., Hareland G. 2010 Variability and relationships among mixolab, mixograph, and baking parameters based on multi-environment spring wheat trials Cereal Chemistry $87(6) \cdot 574-580$ http://dx.doi.org/10.1094/CCHEM-04-10-0068

Cyrkler-Degulıs M., Bulınska-Kadomska Z. 2006. Yielding and healthiness of cultivars and populations of four winter wheat species under organic agriculture conditions. Journal of Research and Applications in Agricultural Engineering, 51 (2): 17-21 (in Polish)

De Vita P., Riefolo C., Codianni P., Cattivelli L., Fares C. 2006. Agronomic and qualitative traits of T. turgidum ssp. dicoccum genntynes cultivated in Italy Funhytica, 150 (1-2): 195-205 http://dx.doi.org/10.1007/s10681-006-9107-6

Dhaka V., Gulıa N., Khatkar B. S. 2012. Application of mixolab to assess the hread making quality of wheat, $183 \mathrm{p}$. http://dx.doi.org/10.4172/scientificreports. 183

Dubat A. 2010. A new AACC international approved method to measure rheological properties of a dough sample. Cereal Fonds World, 55 (3): 150-153

http://dx.doi.org/10.1094/CFW-55-3-0150 
Giacintucci V., Guardeno L., Puig A., Hernando I., Sacchetti G., Pitta P. 2014. Composition, protein contents, and microstructural characterisation of grains and flours of emmer wheats (Triticum turgidum ssp. dicoccum) of the Central Italy type. Czech Journal of Food Science, 32 (2): 115-121

Grobelnik Mlakar S., Bavec F., Bavec M., Jakop M., Robačer M., Brkljača J., Bodroža-Solarov M. 2014. Technological properties of spelt according to different production systems. II International Congress Food Technology, Quality and Safety. XVI International Symposium Feed Technology. Novi Sad, Serbia, 15 p.

Ionescu V., Stoenescu G. 2010. Comparative evaluation of wet gluten quantity and quality through different methods. The Annals of the University Dunarea de Jos of Galati. Fascicle VI - Food Technology, 34 (2): 44-48

Kohajdová Z., Karovičová J. 2008. Nutritional value and baking applications of spelt wheat. Acta Scientiarum Polonorum. Technologia Alimentaria, 7 (3): 5-14

Kohajdová Z., Karovičová J. 2009. Chemical characteristics and pasting properties of commercial Slovak common and spelt wheat flours. Agriculturae Conspectus Scientificus, 74 (4): 313-317

Koksel H., Kahraman K., Sanal T., Ozay D. S., DubatA. 2009. Potential utilization of Mixolab for quality evaluation of hread wheat genntynes Cereal Chemistry 86 (5): 522-526 http://dx.doi.org/10.1094/CCHEM-86-5-0522

Konvalina P., Capouchová I., Stehno Z., Moudrý J. 2010. Agronomic characteristics of the spring forms of the wheat landraces (einkorn, emmer, spelt, intermediate bread wheat) grown in organic farming Inournal of A grohinlogy, 27 (1): 9-17 http://dx.doi.org/10.2478/s10146-009-0002-3,

Konvalina P., Capouchová 1., Stehno L. 2012. Agronomically important traits of emmer wheat. Plant, Soil and Environment, 58 (8): 341-346

Mixolab Application Handbook. Rheological and enzyme analyses. 2012. Villeneuve-la-Garenne, France, p. 62, 70
Nowak W., Zbroszczyk T., Kotowicz L. 2004. Effect of management level on some quality traits of wheat cultivars. Pamiętnik Puławski, 135: 199-212 (in Polish)

Pagnotta M. A., Mondini L., Codianni P., Fares C. 2009. Agronomical, quality, and molecular characterization of twenty Italian emmer wheat (Triticum dicoccon) accessions. Fenetic Resources and Cron Fvolution 56 (3): 299-310 http://dx.doi.org/10.1007/s10722-008-9364-4

Rachon L., Szumiło G., Stankowsk1 S. 2011. Comparison of selected technological value indicators of common wheat (Triticum aestivum ssp. vulgare), durum wheat (Triticum durum) and spelt wheat (Triticum aestivum ssp. spelta). Fragmenta Agronomica, 28 (4): 52-59 (in Polish)

Rachoń L., Szumiło G., Kurzydłowska I. 2013. The effect of the production technology intensity on the quality of common, durum, spelt and enkorn wheat. Annales Universitatis Mariae Curie-Sklodowska Sectio E, Agricultura, 68 (2): 60-68 (in Polish)

Suchowilska E., Wiwart M., Kandler W., Krska R. 2012. A comparison of macro- and microelement concentrations in the whole grain of four Triticum species. Plant, Soil and Environment, 58 (3): 141-147

Szafrańska A., Rachoń L., Szumiło G. 2015. Estimation of protein-starch complex of selected wheat species depending on prodution technology intensity. Zeszyty Problemowe Postępów Nauk Rolniczych, 582: 81-90

Torbica A., Drašković M., Tomić J., Dodif D., Bošković J., Zečević V. 2016. Utilization of Mixolab for assessment of durum wheat quality dependent on climatic factors. Inurnal of Cereal Science 69: 344-350 http://dx.doi.org/10.1016/j.jcs.2016.04.012

Woźniak A. 2006. The yield and quality of grain of spring wheat (Triticum aestivum L.) and hard wheat (Triticum durum Desf.) in dependence on agrotechnical level. Acta Agrophysica, 8 (3): 75-763 (in Polish)

ISSN 1392-3196 / e-ISSN 2335-8947

Zemdirbyste-Agriculture, vol. 103, No. 4 (2016), p. 369-376

DOI 10.13080/z-a.2016.103.047

\title{
Vasarinių kviečių kepimo savybès priklausomai nuo metų derliaus ir auginimo technologijos
}

\author{
L. Rachon, G. Szumilo, A. Szafranska, D. Kotyrba \\ ${ }^{1}$ Liublino Gamtos mokslų universiteto Argoinžinierijos institutas, Lenkija \\ ${ }^{2}$ Wacławo Dąbrowskio žemès ūkio ir maisto pramonès biotechnologijos institutas, Lenkija
}

\section{Santrauka}

Tyrimo tikslas - apibrèžti diferencijuoto agrotechnikos lygio įtaką keturių rūšių vasarinių kviečių: paprastụjų (Triticum aestivum ssp. aestivum L.), kietujų (Triticum durum Desf.), speltos (Triticum aestivum ssp. spelta (L.) Thell) ir dvigrūdžių (Triticum dicoccum (Schrank) Schübler), kokybei. Taikyti du agrotechnikos lygiai: vidutinis - mineralinis tręšimas ( $\mathrm{N}-70, \mathrm{P}-30,5$ ir $\left.\mathrm{K}-99,6 \mathrm{~kg} \mathrm{ha}^{-1}\right)$, sèklų apdorojimas bei piktžolių naikinimas, ir aukštas mineralinis tręšimas ( $\mathrm{N}-140, \mathrm{P}-30,5$ ir $\left.\mathrm{K}-99,6 \mathrm{~kg} \mathrm{ha}^{-1}\right)$, sẻklų apdorojimas bei piktžolių naikinimas, purškimas dviem fungicidais, insekticidu ir auginimo reguliatoriumi. Tirti 2011-2013 m. derliaus gūdų mėginiai. Siekiant nustatyti viso grūdo miltų, gautų iš analizuotų grūdų mèginių, kepimo savybes, ištirta glitimo kiekis ir kokybè, kritimo skaičius ir prietaisu Mixolab - reologinès savybės. Viso grūdo miltų tešlos reologinès savybės priklausė nuo kviečių rūšies ir derliaus nuėmimo metų. Tarp tirtų kviečių rūšių speltos kviečiai turejjo daugiausia šlapiojo glitimo, didžiausią amilolitinių fermentų aktyvumą (C4) ir krakmolo retrogradaciją (C5). Dvigrūdžiai kviečiai pasižymėjo mažiausiu glitimo kiekiu ir tešlos atsparumu maišymui (laikas T1 ir stabilumas). Dvigrūdžiai kviečiai išsiskyre silpniausia baltymų struktūra (aukščiausia vertė - Cs ir C2). Derliaus nuèmimo metai turèjo ịtakos grūdo krakmolo kleisterizacijai (C3), amilolitinių fermenų aktyvumui (C4), krakmolo retrogradacijai (C5) ir krakmolo kleisterizacijos trukmei (T3-T2). Kviečiai, auginti taikant aukšto lygio agrotechniką, turejjo didesni glitimio kieki ir žemesnę krakmolo kleisterizacijos temperatūrą (D3).

Reikšminiai žodžiai: dvigrūdžiai kviečiai, kepimo savybės, kietieji kviečiai, Mixolab, paprastieji kviečiai, speltos kviečiai.

Please use the following format when citing the article:

Rachon L., Szumilo G., Szafranska A., Kotyrba D. Bread-making potential of selected spring wheat species depending on crop year and production technology intensity. Zemdirbyste-Agriculture, 103 (4): 369-376 DOI $10.13080 /$ z-a.2016.103.047 